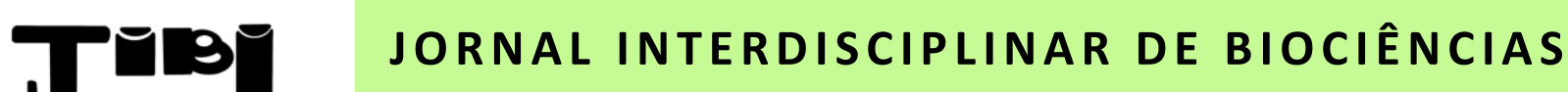

Homepage: http://www.ojs.ufpi.br/index.php/jibi

\section{Descriptive macroscopic anatomy of the central nervous system six-banded armadillo (Euphractus sexcintus, Linnaeus, 1758) and nine-banded armadillo} (Dasypus novemcinctus, Linnaeus, 1758)

\author{
Anatomia macroscópica descritiva do sistema nervoso central do tatu peba (Euphractus \\ sexcintus, linnaeus, 1758) e tatu verdadeiro (Dasypus novemcinctus, linnaeus, 1758)
}

João Victor Silva Araújo ${ }^{1 *}$, Andrezza Braga Soares da Silva ${ }^{1}$, Maria Michele Araújo de Sousa Cavalcante $^{1}$, Paulo César de Jesus Gonçalves ${ }^{1}$, Sergio Paulo Lima Guerra ${ }^{1}$, Aírton Mendes Conde Junior $^{1}$

${ }^{1}$ Department of Morphology, Health Sciences Center, Federal University of Piauí

\begin{abstract}
A B S TR A C T
Armadillos of the species Dasypus novemcinctus and Euphractus sexcintus are xenarthricos mammal that inhabits fields and have several eating habits. This study proposes to analyses the macroscopic anatomy of the nervous system of the nine-banded armadillo and six-banded armadillo. Three animals of each species were donated by Chico Mendes Institute for Biodiversity of the Serra da Capivara National Park, victims of poaching and died. The animals were stored in Histology and Embryology Laboratory of the Morphology Department of Health Sciences Center of the UFPI. Initially, they were fixed with $10 \%$ buffered formalin for 24 hours and then dissected for observation of the organs that forming the central nervous system. The macroscopic morphology, the central nervous system of the Armadillo resembles those of other mammals, however, anatomical features found in the brain and spinal cord suggests a higher olfactory expression and motor skills. It was concluded that are distributed in the regions cervical, thoracic, lumbar, sacral and caudal. But both species have the same number of vertebrae. It is suggested that the vertebrae of the armadillo species $D$. novemcinctus are anatomically larger. It was concluded also that the central nervous system well developed phylogenetically and to maintain the relationship anatomical structure and proper function of your needs.
\end{abstract}

KEYWORDS

Mammal; Brain; Spinal cord

RESUMO

Os tatus das espécies Dasypus novemcinctus e Euphractus sexcintus são mamíferos xenarthricos que vivem em campos e apresentam hábitos alimentares diversos. O presente trabalho propõe uma descrição anatômica do sistema nervoso central do tatu-peba e tatu-verdadeiro, estabelecendo comparações entre ambas as espécies. Foram utilizados três tatus de cada espécie doados pelo Instituto Chico Mendes de Biodiversidade, do Parque Nacional da Serra da Capivara, vítimas da caça predatória e que vieram a óbito. Os animais foram armazenados sob baixas temperaturas no Laboratório de Histologia e Embriologia do Departamento de Morfologia, no Centro de Ciências da Saúde, da UFPI. Após descongelamento, foram então, fixados inicialmente em solução de formaldeído tamponado a $10 \%$ por 24 horas e posteriormente dissecados para observação dos órgãos que compõem o sistema nervoso central. A morfologia macroscópica, o sistema nervoso central das espécies de tatus é muito semelhante ao de outros mamíferos, no entanto, características anatómicas encontradas no cérebro e na medula espinal sugere uma maior expressão e habilidades motoras olfativos. Concluiu-se que são distribuídos nas regiões cervical, torácica, lombar, sacra e caudal. Mas ambas as espécies têm o mesmo número de vértebras. Sugere-se que as vértebras da espécie D. novemcinctus são anatomicamente maiores. Concluiu-se também que o sistema nervoso central bem desenvolvido filogeneticamente e para manter a estrutura e função anatómica relação adequada às suas necessidades.

PALA VRAS - CHAVE

Mamífero; Encéfalo; Medula 


\section{INTRODUCTION}

Etymologically, 'Armadillo', a word derived from the Tupi language means 'hard leather animal' (PEREIRA JUNIOR et al. 2003) due to its well-developed carapace, why are easily identified (SILVA et al. 2007). They have short legs with strong claws and a tough shell, yet flexible coating most of his body. They are mammals Xenarthra Order; relatives of sloths and anteaters and have a normal body temperature ranges $33-35{ }^{\circ} \mathrm{C}$ (TRUMAN et al., 2014).

Anteaters, armadillos and sloths occurs mainly in the eastern part of South America, ranging from southern Amazon region through Brazil to Uruguay, Paraguay, northeastern Argentina and central and eastern of Bolivia. New records have expanded the species distribution area in Brazil, covering the entire state of Maranhão and four new sites in the states of Amapá and Pará. In Brazil, the species occurs in the biomes of the Amazon, Caatinga, Cerrado, Pantanal, Atlantic Forest and Sulinos fields (MEDRI, 2008).

Important to highlight that species of armadillos have several zoonoses, which can affect other animals and even humans (MEDRI, 2010). According to Herrera, in 2009, the nine-banded armadillo (Dasypus novemcinctus) was recognized as one of the natural reservoirs of Chagas disease. Other studies also indicate that serologically positive for toxoplasmosis and leptospirosis kind, this latest when the animals are kept in captivity. Frota (2012) points the six banded of the armadillo (Euphractus sexcinctus) as the main reservoir of the bacillus Mycobacterium leprae.

There is also a relationship between armadillos and fungi because their presence in burrows of land armadillos, such as Paracoccidioides brasiliensis which causes paracoccidioidomycosis, a respiratory mycosis of material impact in Latin America, especially in Brazil (BITTENCOURT, 2002). Thus, there is the great importance of armadillos and therefore the deepest understanding of these animals and their parts, leading to even consider that it is even used as a power source for humans.

According to Padoa, in 2002, because the evolution of organisms, new neural structures of control and necessary adaptations to the perception of environmental stimuli emerged thanks to the development of the brain, particularly in vertebrates. The nervous system has the ability to receive information, for example, when occurs in the external environment (the individual with their environment), establishes and regulates the appropriate responses to maintain balance of the body assuring the survival of the animal. It is also affected by the internal environment, that is, everything that occurs in various regions of the body (MACHADO, 2000).

However, not observed morphological studies related to this species. In the case of the nervous system, in particular, they have not yet been developed research aimed to identifying the central and peripheral organs, despite the importance of this system in the control of homeostasis and in the definition of food search skills and reproductive behavior, for example. Therefore, this study aimed to describe the most obvious structures of the brain six-banded armadillo (Euphractus sexcinctus) and ninebanded armadillo (Dasypus novenvinctus) in order to contribute to the knowledge of the anatomy of these species, enabling comparisons between themselves and with other mammals.

\section{MATERIAL AND METHODS}

Three six-banded armadillos (Euphractus sixcinctus) and three nine-banded armadillo (Dasypus novemcinctus) were used. The animals used were donated by Chico Mendes Institute for Biodiversity (ICMBio), the Serra da Capivara National Park, that died victim of local predatory hunting, authorized by SISBIO (System Authorization and Information on Biodiversity) and led by freezing the Laboratory Histology and Embryology Department of Morphology at the Health Sciences Center of the Federal University of Piauí.

After thawing, the skin of animals were batting to gain access to the thoracic and abdominal cavities, and proceeded with $10 \%$ formalin injection, buffered to $\mathrm{pH} 7.4$, via the left ventricle allowing the perfusion fixative for whole body the animal, including the central nervous system, object of this study. Subsequently the infusion, the animals were plunged into plastic container buffered formalin, $\mathrm{pH} 7.4$, for 24 to 48 hours before proceeding with the dissection.

Armadillos of the species D. novemcinctus were positioned to taken a lateral-lateral and ventral-dorsal radiographs. After 24-48 hours of attachment was held incision confined to the each animal's skull with the help of a scalpel blade number 24, engaged in appropriate cable, opening in sequence, the skullcap of the same with saw to osteotomy, to enable the extraction of the brain and its wraps. It was subsequently sawed the spine of each animal, which contained the spinal cord that could be analyzed, along with their wraps. It was observed before spinal cord removal of medullary levels relative to the levels of the column and the meninges with surrounding bone structures. The opening in the bony portion of said previously column was performed by withdrawal of the transversal spinal processes and by cutting at the level of 
bone blades which connect the transverse spinous processes.

The brain and spinal cord after extracted were fixed in $10 \%$ buffered formaldehyde for 24 hours before handling. The structures were described using the nomenclature of the International Committee on Veterinary Gross Anatomical Nomenclature (2005), and photos documented for each animal, individual results were tabulated.

\section{RESULTS AND DISCUSSION}

The central nervous system six-banded armadillo (Euphractus sexcinctus) and nine-banded armadillo (Dasypus novemcinctus) consists of the brain and spinal cord. The brain of both species appeared divided externally: a pair of olfactory lobes, brain divided into right and left hemispheres, cerebellum and bridge bulb. The spinal cord was observed as a cilindroide nervous tissue mass is located within the spinal canal extending caudally from the bulb and terminating in a tapered region over the conus (DI DIO, 1999).

The cerebellum is responsible essentially of motor functions, balance and control of muscle tone
(SANTOS, 2002), suggesting a larger number of associations between synapses and neurons since the kind shown agile enough to perform a variety of movements both to prey, such as for defending against predators (SILVA et al., 2008). In phylogenetically higher mammals to armadillos show diversification of cerebellar activity. García et al. (2015) assumes that sexually inexperienced rats show increased neural activity after cerebellar vermis be stimulated by the smell of receptive female.

Terminal filament and cauda equina were observed in the six-banded armadillo, common to mammals (Figure 1). Were quantified 31 pairs of spinal nerves and two swelling developed: a cervical and lumbar, representing areas of the spinal cord that receive large amounts of afferent neurons and efferent output respectively of the upper and lower limbs.

The topography of the species $D$. novemcinctus (Figure 3) showed 7 cervical vertebrae, 10 thoracic vertebrae, 5 lumbar vertebrae and fused sacral bone (synsacrum), similar to what was observed by Alberto et al. (2010) in the species E. sexcintus. It can suggest that bone conformations of the two species are geared solely to their way of life as diggers.
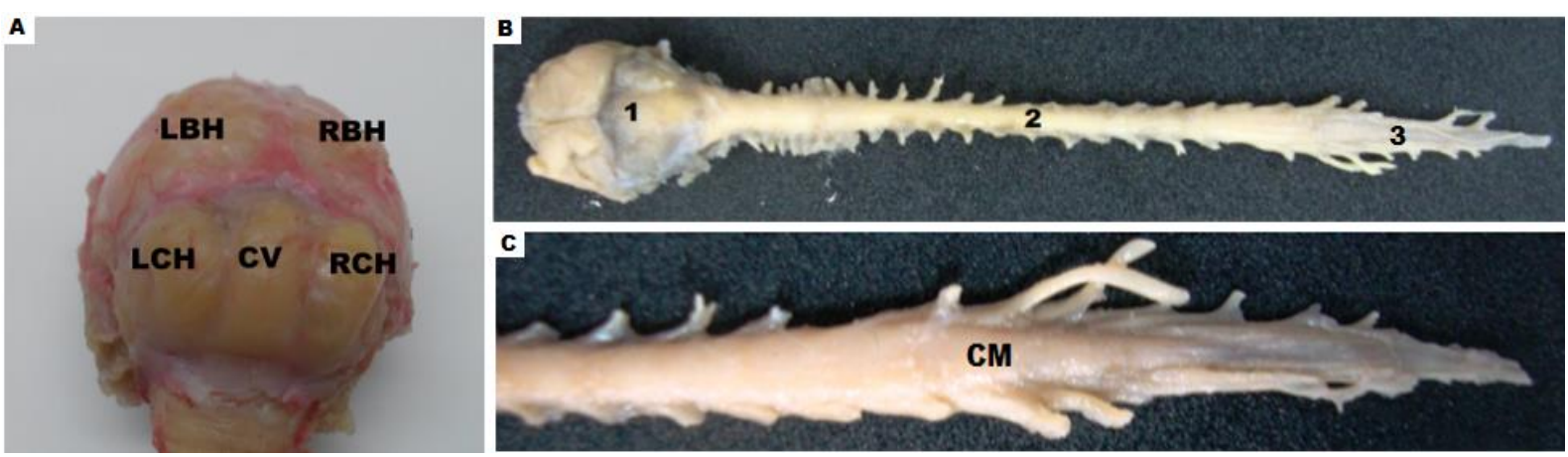

FIGURE 1. (A) Posterior view of encephalon of Euphractus sexcintus showing the left cerebellar hemisphere (LCH), the right cerebellar hemisphere $(\mathrm{RCH})$, vermes cerebelar $(\mathrm{CV})$ proeminent and the dorsal surface of left brain hemisphere (LBH) and right brain hemisphere (RBH). (B) Dorsal surface of brains hemispheres, cerebellum (1) of the spinal cord with spinal nerves (2) and of terminal filament (3). (C) Anterior view of spinal cord showing the lumbar bulge, the conus medullaris (CM) and the cauda equine.

The brains of armadillos have observed its relatively smooth surface, but presents spins and rudimentary grooves. The cerebellum has performed well developed with prominent cerebellar vermis with size larger than the cerebellar hemispheres alone. In zoological range of mammals, the latest animals have large amounts of gyri and sulci in the brain matter, because large amounts of neurons in a small volume. Already in older animals, the cerebral cortex has few gyri and sulci, presenting a flat shape (SILVA et al., 2007).

The brain of the E. sexcintus had on average: the length of the rostral part of the brain to the spinal cord cone of $14.9 \mathrm{~cm}$; length of the brain (the most rostral part of the hemispheres to the foramen magnum, which marks the transition from the bulb to the spinal cord) of $3.5 \mathrm{~cm}$; total length of the spinal cord (the foramen magnum superior, by the end of the medullary cone, inferiorly) of $11.4 \mathrm{~cm}$; the brain circumference of $6.75 \mathrm{~cm}$; circumference average of the spinal cord of $1.1 \mathrm{~cm}$; cervical circumference of the swelling of $1.9 \mathrm{~cm}$; lumbar circumference of the swelling of $1.7 \mathrm{~cm}$ and width of the brain of $1.92 \mathrm{~cm}$.

To the spinal cord, the specimens showed on average the following measurements: length of the bulb to the medullary cone, $9.2 \mathrm{~cm} ; 1.4 \mathrm{~cm}$ of circumference; cervical circumference of the swelling of $2.2 \mathrm{~cm}$; and swelling of the lumbar circumference of $1.7 \mathrm{~cm}$. 

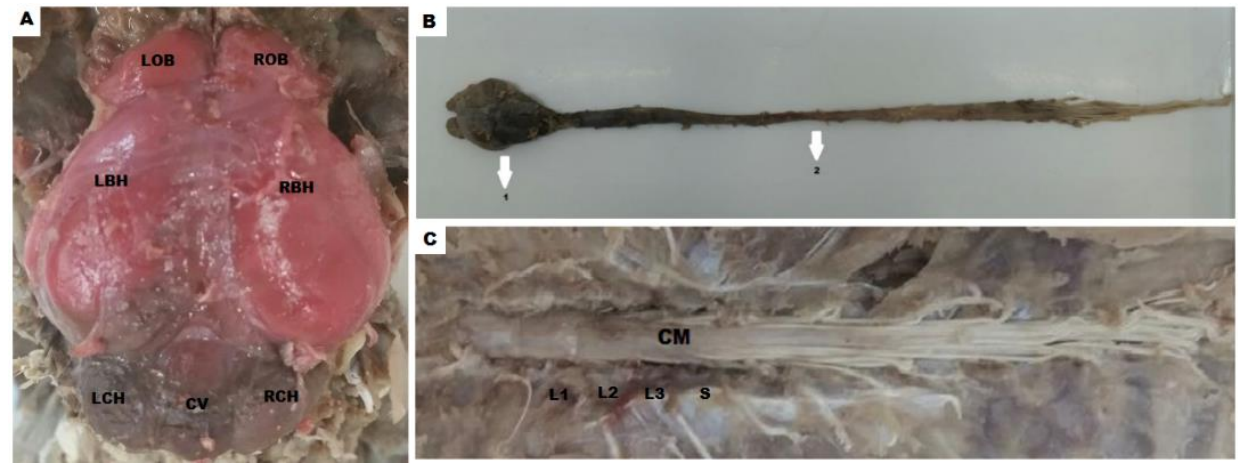

FIGURE 2. (A) Dorsal aspect of the encephalon of Dasypus novemcinctus. (B) Dorsal surface of brains hemispheres, cerebellum and spinal cord. (C) The conus medullaris (CM) of Dasypus novemcinctus male in dorsal view that extends from L2 to S, the lombar bulge between L1 and L3 and the cauda equina that start in S.
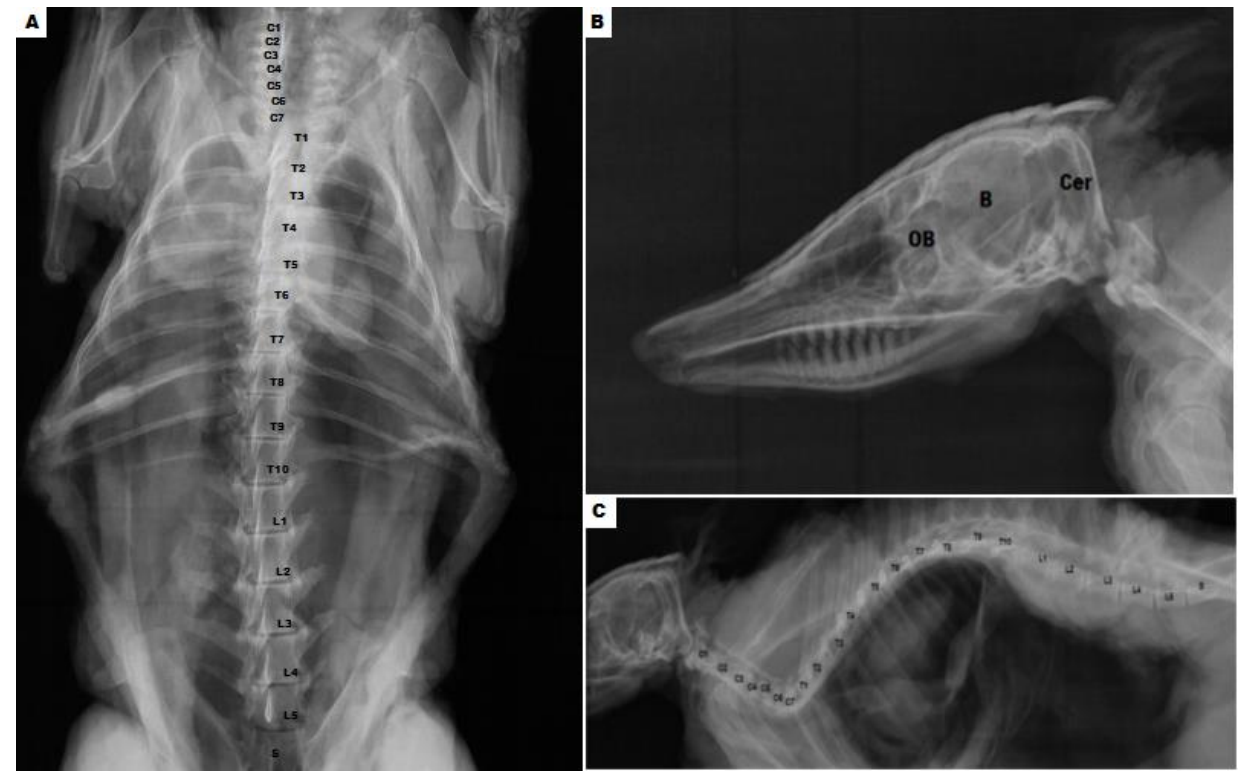

FIGURE 3. Radiographic photographic of nine-banded armadillo (Dasypus novemcinctus) in the positions: ventro-dorsal (A), left lateral-lateral of skull (B) and left lateral-lateral of body (C). It were observed seven cervical vertebrae (C1-C7), ten toracic vertebrae (T1-T10), five lumbar vertebrae (L1-L5), the sacral vertebrae fused (S), the olfatory bulb (OB), the brain (B) and the cerebellum (Cer).

The brain copies of D. novemcinctus (Figure 2) showed on average: the length of the rostral part of the brain to the spinal cord cone of $29 \mathrm{~cm}$; length of the brain (the most rostral part of the hemispheres to the foramen magnum, which marks the transition from the bulb to the spinal cord) of $4 \mathrm{~cm}$; total length of the spinal cord (the foramen magnum superior, by the end of the medullary cone, inferiorly) of $24 \mathrm{~cm}$; circumference of the brain of 7 $\mathrm{cm}$; average circumference of the spinal cord of $1.1 \mathrm{~cm}$; circumference of cervical bulge of $1.3 \mathrm{~cm}$; circunference of lumbar bulge of $2.3 \mathrm{~cm}$ and width of the brain of $3 \mathrm{~cm}$.

To the spinal cord, the specimens showed on average the following measurements: length of the bulb to the medullary cone, $21 \mathrm{~cm}$ with $1.4 \mathrm{~cm}$ of circumference; circunference of the bulge cervical of $2.2 \mathrm{~cm}$; and swelling of the lumbar circumference of $1.7 \mathrm{~cm}$. The dissection of lumbar-sacral spinal cord specimens analyzed in $D$. novemcinctus revealed that the base of the conus medullaris was found situated on the third lumbar vertebra (L3), the cone apex is located on the sacral vertebra (S). The importance of these data reflects the great importance in relation to epidural anesthesia in different animal species. Despite the dimensions, the region sacred is shown as the ideal access to anesthetic procedures in this species (ALBERTO et al., 2010).

\section{CONCLUSION}

The findings support the conclusion that the sixbanded armadillo species and Dasypus novemcinctus presents a central nervous system well developed phylogenetically and to maintain the relationship anatomical structure and proper function of your needs. It was concluded also that the bone structure of the two species is effectively shown to the way of life of these animals like burrowing mammals. 


\section{REFERENCES}

ALBERTO, M. L. V.; OLIVEIRA. C. M.; RODRIGUES, M. N.; OLIVEIRA, A. B.; MIGLINO, M. A.; AMBRÓSIO. C. E. Funções ósseas do esqueleto de tatu (Euphractus sexcinctus). Acta Veterinaria Brasilica, v.4, n.2, p. 86-91, 2010

BITTENCOURT, J. I. M., Mortalidade por paracoccidioidomicose no estado do Paraná, Brasil (1980-1998). Ponta Grossa, 2002. 60f. Dissertação (Mestrado). Universidade Estadual de Ponta Grossa. 2002.

DI DIO, J. L. A. Tratado de anatomia sistêmica aplicada. 2. ed. São Paulo: Atheneu, 1999. v. 2.

FROTA, C. C., LIMA, L. N., ROCHA, A. D. A. S., SUFFYS, P. N., ROLIM, B. N., RODRIGUES, L. C., BARRETO, M. L., KENDALL, C., KERR, L. R. Mycobacterium leprae in six-banded (Euphractus sexcinctus) and nine-banded armadillos (Dasypus novemcinctus) in Northeast Brazil. Mem. Inst. Oswaldo Cruz [online], v.107, n.1, pp. 209-213, 2012.

GARCÍA L. I.; GARCÍA-BÃ NUELOS, P.; ARANDAABREU, G. E; HERRERA-MEZA, G.; CORIA-AVILA, G. A.; MANZO, J. Activación del cerebelo por estimulación olfativa em ratas macho sexualmente inexpertas. Neurología.v. 30, p. 264-269, 2015.

HERRERA, H. M. Laboratório de Biologia de Tripanossomatídeos, Instituto Oswaldo Cruz, Fiocruz, Ministério da saúde, 2009. Disponível em: http://www.fiocruz.br/chagas/cgi/cgilua.exe/sys/start.htm. ?sid=114. Acesso em: 10 de setembro de 2015 .

MACHADO, A.B. Neuroanatomia functional. São Paulo: Atheneu, 2000.

MEDRI, I. M. Ecologia e história natural do tatu-peba, Euphractus sexcinctus (Linnaeus, 1758), no Pantanal da Nhecolândia, Mato Grosso do Sul. Brasília: 2008. 167f. Tese (Pós-Graduação em Ecologia) - Instituto de Ciências Biológicas, Universidade de Brasília, Brasília, 2008.

MEDRI, I. M.; MARTINS, J. R.; DOYLE, R. L.; MOURÃO, G.; MARINHO FILHO, J. Ticks (Acari: Ixodidae) from yellow armadillo, Euphractus sexcinctus (Cingulata: Dasypodidae), in Brazil's Pantanal wetlands. Neotrop. entomol. [online]. v. 39, n. 5, p. 823-825, 2010.

PADOA, E. Manuale di anatomia comparata dei vertebrati. 18.ed. Milão: Giangiacomo Feltrinelli, 2002.

PEREIRA JUNIOR, H. R. J.; JORGE, W.; BAGAGLI, E. Por que tatu? Revista Ciência Hoje, v. 34, n. 199, p. 7073, 2003.

SANTOS, R. O., Estrutura e funções do córtex cerebral Brasília, 2002. 29f. Monografia (Graduação) - Centro Universitário de Brasília, Brasília, 2002.
SILVA, D. F.; FILHO, J. G.; BAGAGLI, E. Anatomia do encéfalo de Dasypus novemcinctus (xenarthra, dasypodidade). Arq. Ciênc. Vet. Zool. Unipar, Umuarama, v. 10, n. 1, p. 27-29, 2007.

SILVA, P. H. C.; SILVA, R. M.; LIMA, E. M. M. Topografia das intumescências cervical e lombar em gatos sem raça definida (Felis catus Linnaeus, 1758). Ciência Animal Brasileira, v. 9, n. 4, p. 1089-1095, 2008.

TRUMAN, R. W.; EBENEZER, G. J.; PENA, M. T.; SHARMA, R.; BALAMAYOORAN, G.; GILLINGWATER, T. H., SCOLLARD, D. M., MCARTHUR, J. C.; RAMBUKKANA, A. The armadillo as a model for peripheral neuropathy in leprosy. Ilar. Journal. v. .54, n. 3, p. 304-314, 2014. 